\title{
Conformational mobility investigation of TyrRS C-module and its complex with tRNA using the methods of time-resolved fluorescence spectroscopy
}

\author{
M. O. Kordysh, G. V. Kyryushko, Y. Mely'1, O. I. Kornelyuk \\ Institute of Molecular Biology ad Genetics NAS of Ukraine \\ 150, Zabolotny Str., Kyiv, 03143, Ukraine \\ ${ }^{1}$ Louis Paster University \\ Strasbourg, F-67401, France \\ kordysh@yahoo.com
}

\begin{abstract}
The non-catalytic C-module formed after proteolytic cleavage of full-length mammalian tyrosyl-tRNA synthetase displays RNA-binding ability. C-module contains a unique tryptophan residue (Trp144), located out of its RNA-binding site, and a conservative aromatic residue Phe127 located inside of its RNA-binding site, which was replaced by fluorophore Trp127. Obtained fluorescence decay parameters of free C-module Trp144 and its complex with $T R N A$ detect the absence of tRNA-interaction sensitivity. Obtained fluorescence decay parameters of Trp 144 and Trp 127 of C-module and its complex with $t R N A$ are characterized by the additional short-lived component without any sufficient changing of other fluorescence parameters in the presence of nucleic acid. It indicates the existence of the polymorphism of Trp127 microsurrounding that is conditioned by the dynamic protein-nucleic acid interaction mechanism.
\end{abstract}

Keywords: tyrosyl-tRNA synthetase C-module time-resolved fluorescence spectroscopy, conformational mobility.

Introduction. Cytoplasmic tyrosyl-tRNA synthetase (TyrRS) of mammals consists of two structural modules as follows: $\mathrm{NH}_{2}$-terminal catalytic module and cytokine-like COOH-terminal domain, cytokine EMAP II homologue (endothelial and monocyte-activating polypeptide II) $[1,2]$. Non-catalyzing C-domain of cytoplasmic TyrRS of mammals has the double function: i) participates in binding tRNA as cys-factor and (ii) after proteolytic cleavage of the catalytic core of synthetase, it reveals its cytokine EMAP II-similar activity $[1,2]$. However the structural aspects of interaction of isolated TyrRS C-module with tRNA as well as the nature of conformational changes in complex and

(C)M. O. KORDYSH, G. V. KYRYUSHKO, Y. MELY, O. I. KORNELYUK, 2007 the functional role of specific amino acid residues remain unknown. Earlier we have investigated self-fluorescence of tryptophan and the conformational mobility of isolated C-module of TyrRS using Trp144 as fluorescent probe [3-5].

The presence of fast conformational mobility of $\mathrm{C}$-module in the range of nanoseconds has been shown $[3,5]$. Trp144 fluorescence is known to be sensitive towards the conformational changes in protein, i.e. conformational transition of Trp144 microsurrounding at heat denaturation of $\mathrm{C}$-module in the range of $40-50^{\circ} \mathrm{C}$ has been determined [4, 5]. However, the study of structural aspects of interaction of isolated C-module with tRNA and the nature of conformational changes in complex was limited by the fact that the 
probe in protein structure - Trp144 fluorophore - was shown to be localised outside of RNA-binding centre and low-sensitive to interaction with nucleic acid. Besides, our previous experiments revealed the interaction of C-module with tRNA to be accompanied by high aggregation of protein in the solution, which is of significant influence on the accuracy of binding parameters determination [6].

Thus, in order to study the interaction of C-module with RNA, we have substituted the conservative aromatic residue Phe127 in RNA-binding centre for fluorophore Trp127 using the method of site-directed mutagenesis [6]. This substitution allowed determining parameters for C-module-tRNA binding and proposing the hypothesis on possible functional role of Trp127 in interaction with nucleic acid (NA) via stacking interaction of aromatic residue with tRNA basis. TyrRS $\mathrm{C}$-module belongs to the group of tRNA-binding factors [7-9], which also includes oligonucleotide-binding fold (OB-fold) [10].

It is noteworthy that all OB-fold proteins have conservative aromatic residues in RNA-binding centres, which are functionally important during the complex formation with tRNA. tRNA-binding factors are characterized by wide range specificity to binding various tRNA [7-9], therefore, we used tRNA ${ }^{\text {Phe }}$ as model structure for C-module and EMAP II interaction with RNA. Therefore, the aim of our work was to study the interaction of C-module TyrRS with tRNA using the methods of time-resolved fluorescence spectroscopy with the purpose of studying conformational changes in protein at interaction with NA and to determine the functional role of residue Trp127.

Materials and Methods. Recombinant proteins of TyrRS C-module and C-module TyrRS with Trp127-for-Phe127 substitution were expressed in Escherichia coli cells and purified to achieve homogenous condition ( $>95 \%$ ) using the methods of metal-chelating chromatography as earlier described in [4-6]. After purification, recombinant proteins were chipped off of His-tag sequence using enterokinase (BioLabs, USA).

Protein and tRNA ${ }^{\text {Phe }}$ (Sigma, USA) solutions applied to study protein-NA complexes using the methods of fluorescece spectroscopy were prepared in buffer of

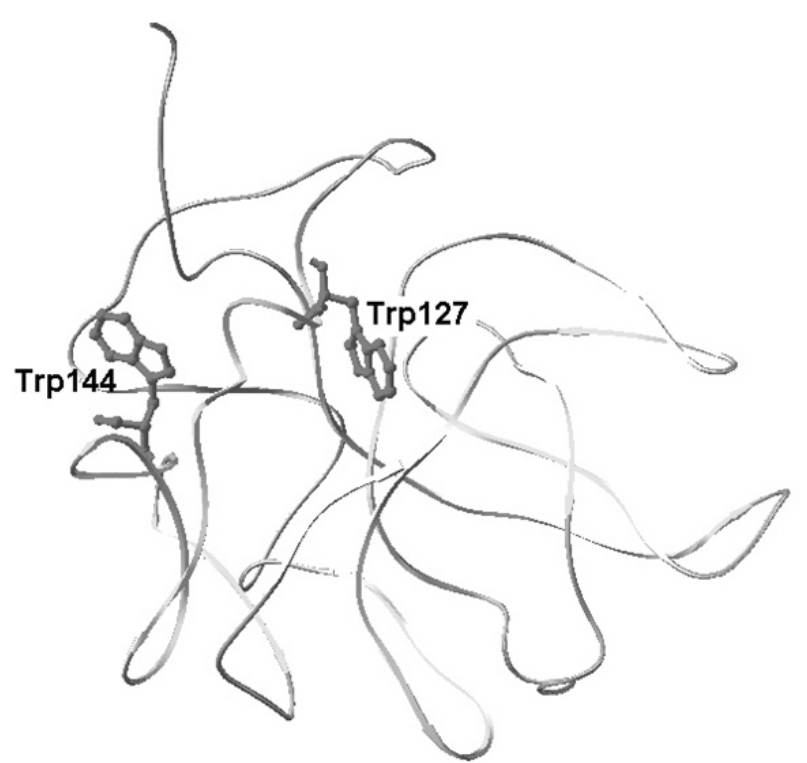

Fig.1 3D-structure of C-module of tyrosyl-tRNA synthetase with substituted Phe127 $\rightarrow$ Trp127

the following content: $20 \mathrm{mM}$ tris- $\mathrm{HCl}, \mathrm{pH} 7.7$, containing $100 \mathrm{mM} \mathrm{NaCl}$ and $5 \mathrm{mM} \mathrm{MgCl}_{2}$.

Concentrations of $\mathrm{tRNA}^{\mathrm{Phe}}$ and proteins were determined using the method of spectrophotometry, extinction coefficients were as follows: $e_{280}=9650$ $\mathrm{M}^{-1} \mathrm{~cm}^{-1}$ (C-module), $e_{280}=15470 \mathrm{M}^{-1} \mathrm{~cm}^{-1}$ (C-module with Phe127 $\rightarrow$ Trp mutation), $e_{260}=500000 \mathrm{M}^{-1} \mathrm{~cm}^{-1}$ (yeast tRNA $\left.^{\text {phe }}\right)$. UV-absorption spectra were measured using Specord UV VIS spectrophotometer (Carl Zeiss, Germany) quartz cuvettes with optical path of $1 \mathrm{~cm}$.

The measuring using time-resolved fluorescece spectroscopy was performed in the mode of singular photons calculation using Ti-sapphire laser (Tsunami, Spectra-Physics, USA), pumpud by a continuous wave argon laser. The excitation wavelength was set at 295 $\mathrm{nm}$. The emission wavelength was set at $340 \mathrm{~nm}$, and detected after the crossing of polarizer oriented at magic angle $\left(54.7^{\circ}\right)$, to eliminate any polarization bias due to molecular rotation. The instrumental response function, recorded with a polished aluminium reflector, has a full width of half-maximum of $\sim 40$ ps. Data analysis of the fluorescence intensity decays was performed by the maximum entropy method (MEM) with Pulse5 software [11]. 
Table 1

Fluorescence decay parameters of TyrRS C-module in free state and in the presence of tRNAPhe at different temperatures

\begin{tabular}{|c|c|c|c|c|c|c|}
\hline \multirow{2}{*}{$\begin{array}{l}\text { Radiation wave } \\
\text { length, } 340 \mathrm{~nm}\end{array}$} & \multicolumn{3}{|c|}{ C-module TyrRS } & \multicolumn{3}{|c|}{ C-module TyrRS in the presence of $\mathrm{tRNA}^{\mathrm{Phe}}$} \\
\hline & $\tau_{\mathrm{i}}, \mathrm{ns}$ & $\alpha_{i}$ & $f_{i}$ & $\tau_{i,} \mathrm{~ns}$ & $\alpha_{i}$ & $f_{i}$ \\
\hline \multirow[t]{3}{*}{$20^{\circ} \mathrm{C}$} & $0.217 \pm 0.103$ & $0.052 \pm 0.031$ & 0.012 & $0.178 \pm 0.042$ & $0.166 \pm 0.102$ & 0.038 \\
\hline & $0.715 \pm 0.021$ & $0.83 \pm 0.016$ & 0.650 & $0.715 \pm 0.016$ & $0.737 \pm 0.022$ & 0.672 \\
\hline & $2.61 \pm 0.548$ & $0.118 \pm 0.019$ & 0.337 & $2.409 \pm 0.392$ & $0.094 \pm 0.007$ & 0.290 \\
\hline \multirow[t]{2}{*}{$37^{\circ} \mathrm{C}$} & $0.437 \pm 0.033$ & $0.819 \pm 0.074$ & 0.568 & $0.500 \pm 0.047$ & $0.843 \pm 0.026$ & 0.588 \\
\hline & $1.812 \pm 0.350$ & $0.151 \pm 0.080$ & 0.432 & $1.877 \pm 0.243$ & $0.157 \pm 0.036$ & 0.412 \\
\hline
\end{tabular}

Note: $\tau_{i}$, ns -fluorescence lifetime; $\alpha_{i}$-the relative proportion of each lifetime class; $f_{i}$ - fractional intensity of each lifetime class.

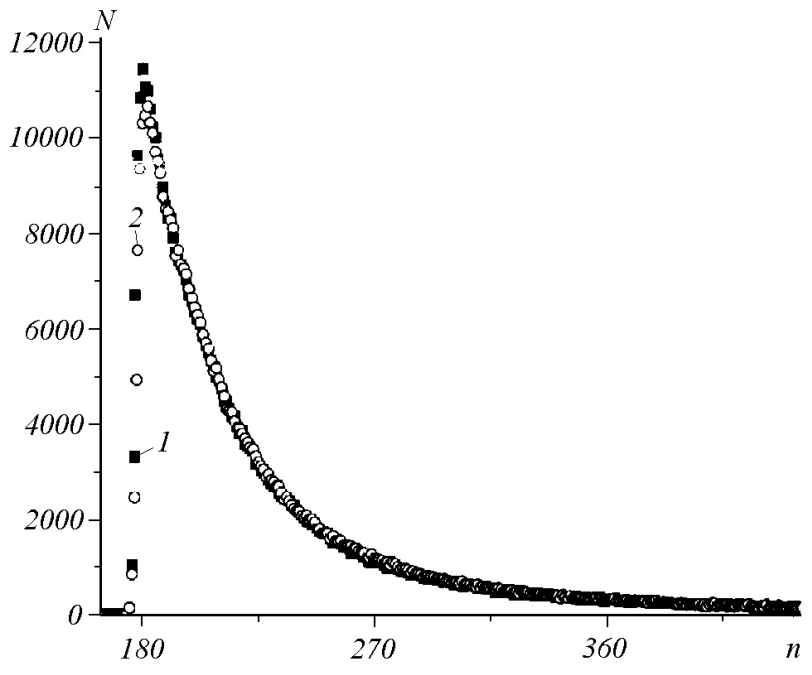

Fig.2 Fluorescence decay of C-module TyrRS (1) and C-module TyrRS in the presence of tRNA ${ }^{\text {Phe }}(2)$ at $20^{\circ} \mathrm{C}(\mathrm{N}-$ the number of counts; $n-$ No. of analyser channel)

Fractional intensity, $f_{\mathrm{i}}$, of each lifetime class was determined according to the formula:

$$
f_{i}=\frac{\alpha_{i} \tau_{i}}{\sum \alpha_{j} \tau_{j}}
$$

where $\tau \mathrm{i}$ - fluorescence lifetime, $\alpha \mathrm{i}$ - relative proportion og each lifetime class [12].

Analysis of Trp127 C-module microsurrounding with Phe127 $\rightarrow$ Trp 127 substitution was carried out using free distributed SwissPDB-Viewer 3.7(b2) software, based on spatial C-module structure cm5 [13]. The structure of TyrRS C-module (cm5) with tRNA ${ }^{\text {phe }}$ (crystal structure of yeast tRNA ${ }^{\text {Phe }}$, PDB ID:1EHZ) was reconstructed using ZDOCK software. In order to improve the quality of the complex after docking, energy minimisation of the complex has been performed, in the process tRNA remained stable and structure of C-module was minimised in the field of tRNA.

Results and Discussion. Our previous works presented the analysis of TyrRS C-module fluorescence, determined by the presence of Tpr144 residue [3-5] and the fluorescence of C-module with Phe127 $\rightarrow$ Trp 127 substitution (Fig.1), which is defined by two fluorophores, namely Trp144 and Trp127 [6]. The values of quantum yield of both $\mathrm{C}$-module with only Trp144 (q=0.09) and C-module with Phe127 substituted for $\operatorname{Trp}(\mathrm{q}=0.298)$ have been calculated. Therefore, fluorescence of mutant C-module Phe127 $\rightarrow$ Trp is determined predominantly by emission of $\operatorname{Trp} 127$ residue, localised in RNA-binding center. It has been shown earlier that Trp144 is screened from solvent molecules and remains in hydrophobic surrounding [3-5], while Trp127 in mutant protein is partially exposed towards solvent molecules. As aromatic residues Trp144 and Trp127 are located in different microsurroundings of protein globula, the decay of their fluorescence intensity is very likely to be characterised by different lifetimes, which may be determined for each fluorophore.

We have studied the fluorescence intensity decay of Trp144 in C-module of TyrRS in free state and in the presence of tRNA ${ }^{\text {Phe }}$ at 20 and $37^{\circ} \mathrm{C}$. The obtained ex- 


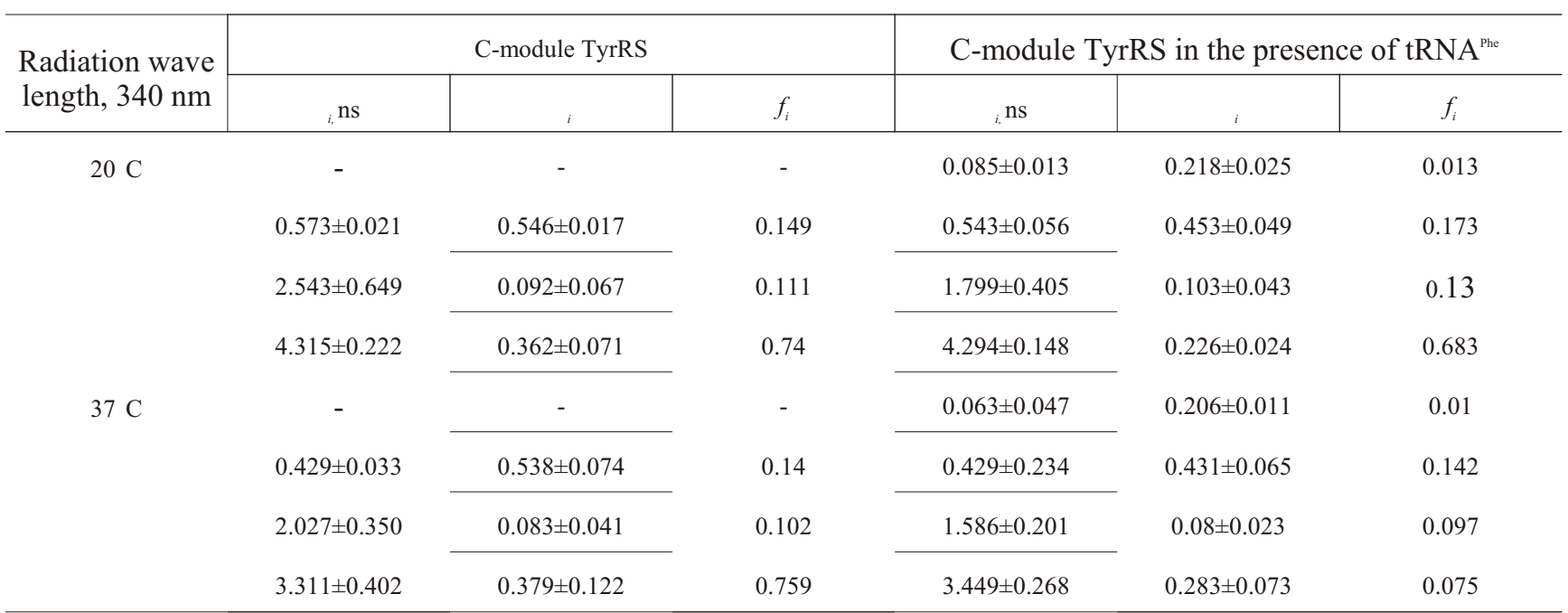

Note: $\tau_{i} n s$-fluorescence lifetime; $\alpha_{i}$-the relative proportion of each lifetime class; $f_{i}$-fractional intensity of each lifetime class.

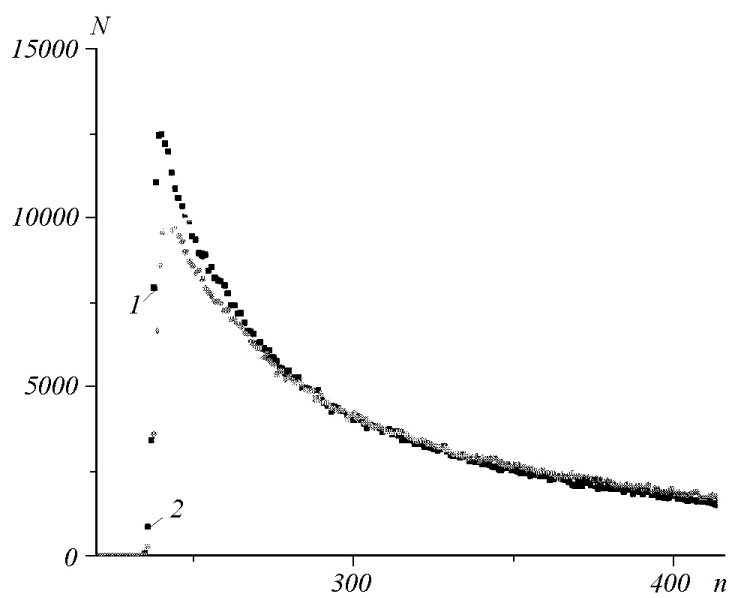

Fig.3 Fluorescence decay of TyrRS C-module with substituted Phe127 $\rightarrow$ Trp in a free state (1) and in the presence of tRNA ${ }^{\text {Phe }}(2)$ at $20^{\circ} \mathrm{C}(\mathrm{N}-$ the number of counts; $n$ - No. of analyser channel)

perimental curves of fluorescence decay are presented in Fig. 2 and the calculated values of the fluorescence decay parameters are presented in Table 1 . As it is seen, the fluorescence decay parameters of Trp144 C-module in free state and in the presence of tRNA ${ }^{\text {Phe }}$ present no significant differences and are showed a trimodal distribution of lifetime peaks at $20^{\circ} \mathrm{C}$ and bimodal distribution at $37^{\circ} \mathrm{C}$. The main contribution in Trp 144 fluorescence decay at $20^{\circ} \mathrm{C}(\sim 65 \%)$ is made by component of $\tau=0.7 \mathrm{~ns}$ and at $37^{\circ} \mathrm{C}(\sim 57 \%) \tau=0.4$ ns (Table 1). At $20^{\circ} \mathrm{C}$, short-lived lifetime ( $\tau=0.2 \mathrm{~ns}$ ) may be considered uncertain as its amplitude equals to the accuracy of the experiment.

Therefore, almost complete absence of changes in fluorescence decay parameters of Trp144 of C-module in the precence of $\mathrm{tRNA}^{\text {Phe }}$ testifies to insensitivity of current fluorophore to NA interaction, which may be explained by its significant distance from $\mathrm{tRNA}^{\mathrm{Phe}}$ binding site (Fig.1).

Our further investigation of C-module involved the development of the substitution of conservative Phe127 residue in RNA-binding site for Trp127 fluorophore using the methods of site-directed mutagenesis.

Fig. 3 presents the C-module fluorescence decay curves with substituted Phe127 $\rightarrow$ Trp and its complex with $\mathrm{tRNA}^{\text {Phe }}$ at $20^{\circ} \mathrm{C}$ which differs significantly. Fluorescence decay parameters of mutant $\mathrm{C}$-module with substituted Phe127 $\rightarrow$ Trp (Table 2) are characterised by trimodal distribution. Taking into account the aforementioned fluorescence lifetime values of Trp144, the values of long-lived fluorescence lifetimes of C-module with substituted Phe127 $\rightarrow$ Trp may be clearly ascribed to each of the tryptophan residues, i.e. $4.3 \mathrm{~ns}-$ $\operatorname{Trp} 127 ; 2.5 \mathrm{~ns}-\operatorname{Trp} 144$ at $20^{\circ} \mathrm{C}$ and $3.3 \mathrm{~ns}-\operatorname{Trp} 127$ and $2 \mathrm{~ns}$ at $37^{\circ} \mathrm{C}$ respectively. It is noteworthy to mention that being in the presence of tRNA, the distribution of Trp lifetimes is characterised by additional short-lived lifetime class ( $\tau=0.09 \mathrm{~ns}$ ), which contrib- 


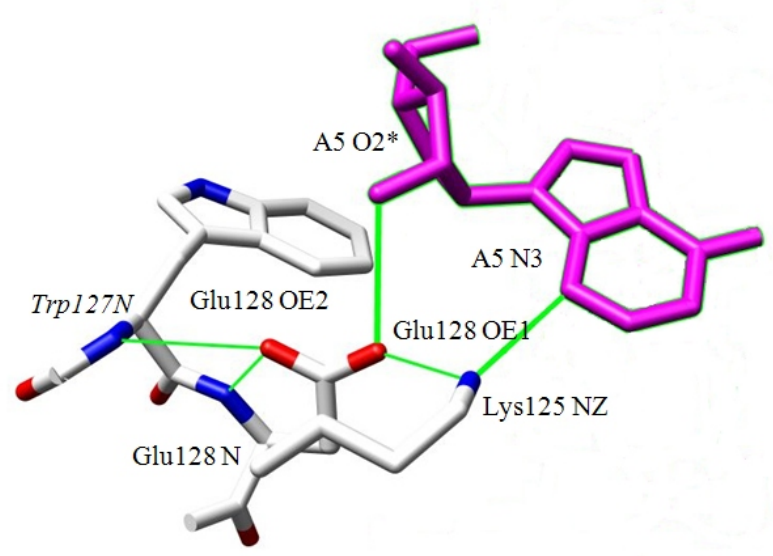

Fig.4 Hydrogen bonds formed by the Glu 128 residue of the C-module in complex with tRNA according to three-dimentional model of the complex

utes $\sim 20 \%$ of the total fluorescence intensity (Table 2 ) at $20^{\circ} \mathrm{C}$ and $37^{\circ} \mathrm{C}$.

Trp144 has been shown to be located outside of the tRNA $^{\text {Phe }}$ binding site and its fluorescence decay parameters do not change at the presence of tRNA ${ }^{\text {Phe }}[6]$, therefore the occurrence of short-lived lifetime peak is determined by additional residue of $\operatorname{Trp} 127$.

The analysis of fluorescence decay parameters of C-module with substituted Phe127 $\rightarrow$ Trp in the presence of tRNA indicates the presence of different populations of tryptophan, the fluorescence of $\sim 20 \%$ of tryptophan residues are quenched in the presence of tRNA, which appeared as an additional short-lived lifetime . Similar heterogeneity of tryptophan populations may be explained by dynamic mechanism of protein-NA interaction and could be associated with a different conformations of $\operatorname{Trp} 127$ in the presence of tRNA.

The appearance of ultrashort lifetime peaks of C-modulw complexed to tRNA ${ }^{\text {phe }}$ could be associated with both a stacking of Trp127 with tRNA bases and conformational changes in protein structure, determined by interaction with $\mathrm{tRNA}^{\mathrm{Phe}}$.

Nonradiative Trp fluorescence quenching is accompanied by the appearance of subnanosecond lifetime component. His side chains in the protonate form, Cys and its disulphide bridges, Glu, and polypeptide backbone are the main quenchers of tryptophan fluorescence [14-16]. In connection to the mentioned above we analysed the microsurrounding of Trp127 in the model of 3D-structure of C-module cm5 [13] and revealed potential acceptors of excited-state electron, namely, amino acid residues Gln131, Glu128, Cys63, and Cys81, located at $10 \AA$ from CE3 atom of tryptophan indole ring. Fluorescence quenching of Trp127 C-module in complex with tRNA by the way of the excited state electron transfer from Trp127 to the aforementioned amino acids side chains may take place at the case of existence of Trp127 rotamers, as a result of conformational change at the interaction with tRNA.

Having studied the structures of C-module complex with tRNA $^{\text {Phe }}$, it was shown that excited-state electron transfer may take place from Trp127 of C-module via alternative way. The position of carboxyl group of Glu128 of C-module complexed with tRNA is stabilised by four hydrogen bonds (Fig.4), which allows the excited-state electron transfer from $\operatorname{Trp} 127$ to $\mathrm{C}=\mathrm{O}$ group Glu128, which results in nonradiative Trp127 fluorescence decay. Worthy of attention is the fact that such stabilisation of $\mathrm{C}=\mathrm{O}$ group Glu128 for $\mathrm{C}$-module is not observed without tRNA.

It should be noted also that [17] shows the dependence of effectiveness of tryptophan fluorescence quenching by $\mathrm{C}=\mathrm{O}$ groups on the distance between fluorophore and quencher group, which, in its turn, influences significantly the value of fluorescence lifetime, i.e. it has been indicated that at $5 \mathrm{E}$ distance between tryptophan $\mathrm{CE} 3$ atom and $\mathrm{C}=\mathrm{O}$ group, the value of short-lived lifetime component of tryptophan fluorescence is $0.09 \mathrm{~ns}$.

According to the model of $\mathrm{tRNA}^{\mathrm{Phe}}$ with $\mathrm{C}$-module the distance between CE3 atom of $\operatorname{Trp} 127$ to $\mathrm{C}=\mathrm{O}$ Glu128 is $\sim 4.3 \AA$ Therefore, the appearance of short-lived lifetime $(0.09 \mathrm{~ns})$ at the C-module compexed to tRNA is most likely to be determined by the excited-state electron transfer from $\operatorname{Trp} 127$ to $\mathrm{C}=\mathrm{O}$ group of Glu128 at the formation of new complex.

We have studied the fluorescece resonance energy transfer (FRET) efficiency from Trp144 of C-module to $\mathrm{Y}$-nucleoside of tRNA ${ }^{\text {phe }}$, which allowed evaluate the distance between these fluorophores. It has been defined that the excitation and emission spectra of tRNA ${ }^{\mathrm{Phc}}$ did not change in the presence of $\mathrm{C}$-module. The latter 
testifies in favour of energy transfer from Trp144 protein to Y-nucleoside, localised in anticodon loop of tRNA $^{\text {Phe }}$. As the value of Ferster distance for current donor-acceptor pair is $1.4 \mathrm{~nm}$, the absence of FRET indicates that the Trp144 residue and Y-base is located at the distance of $r>1.4 \mathrm{~nm}$, which is correlated well with the modelled complex, according to which C-domain of TyrRS interacts with acceptor stem and D-loop of tRNA.

Conclusions. The investigation on TyrRS C-module and its complex with tRNA ${ }^{\text {phe }}$ using the methods of time-resolved fluorescece spectroscopy allowed obtaining new information on conformational changes in Trp144 and Trp127 surroundings. Thus, constancy of the Trp144 fluorescence decay parameters indicates its insensitivity towards interaction with NA which is correlated well with the foot-printing data and the data of molecular modelling on localisation of current residue outside of tRNA binding site. Analysis of fluorescence decay parameters of TyrRS C-module with substituted Phe127 $\rightarrow$ Trp was shown the existence of several tryptophan populations at the interaction with tRNA. This fact shows the presence of polymorphism in microsurrounding of Trp127 residue, which is most likely conditioned by dynamic mechanism of protein-NA interaction and conformational changes in RNA-binding site of the protein.

The authors express their gratitude to Dr. G. Duportale and Dr. E. Pemon for technical support in carrying out the fluorescent measuring and to D. B. Kovalsky for C-module-tRNA model constructing as well as for the discussion of the results. The work was financially supported by grant No. 5.07/200 of Fundamental Research State Fund of Ministry of Science and Education of Ukraine.

\section{М. А. Кордыи, А. В. Кирюшко, І. Мели, А. И. Корнелюк}

Исследование конформационной подвижности С-модуля тирозил-тРНК синтетазы и его комплекса с тРНК методами флуоресцентной спектроскопии с временным разрешением

\section{Резюме}

С-модуль тирозил-тРНК синтетазы млекопитающих проявляет двойную функиию: участвует в связывании тРНК как изис-фактор и после протеолитического отщепления от $N$-кониевого каталитического кора синтетазы проявляет ЕМАР II-подобную ичитокиновую активность. В его структуру входит природный флюорофор Тrр144, который, однако, локализован вне РНК-связывающего сайта. Методом сайт-направленного мутагенеза в РНК-связывающий сайт был введен дополнительный флюорофор за счет замещения консервативного ароматического остатка Phe127 на Trp127. Проведено исследование взаимодействия C-модуля с методами флуоресцентной спектроскопии с временным разрешением. Сравнительный анализ параметров затухания флуоресиениии мутантного C-модуля с заменой Phe127>Trp и его комплекса $c$ mPHК позволил обнаружить дополнительную короткоживущую компоненту триптофановой флуоресиенции в присутствии нуклеиновой кислоты без существенных изменений других параметров. Полученные данные свидетельствуют о полиморфности микроокружения остатка Trp127 в комплексе, обусловленной динамическим механизмом взаимодействия белка с нуклеиновой кислотой.

Ключевые слова: С-модуль тирозил-тРНК синтетазы, флуоресиентная спектроскопия с временным разрешением, конформаиионная подвижность.

\section{REFERENCES}

1. Kornelyuk A. I., Tas M. P. R., Dubrovsky A. L., Murray J. C. Cytokine activity of the non-catalytic EMAP-2-like domain of mammalian tyrosyl-tRNA synthetase // Biopolimery i kletka.-1999.-15, № 2.-P. 168-172.

2. Wakasugi K., Schimmel P. Two distinct cytokines released from a human aminoacyl-tRNA synthetase // Science.-1999-284.-P. $147-151$.

3. Кордыш М. А., Одынец К. А., Корнелюк А. И. Тrp144 как флуоресцентный зонд для изучения конформационной подвижности С-модуля эукариотической тирозил-тРНК синтетазы // Біополімери і клітина.-2003.-19, № 5.- C. $436-439$.

4. Кордыш М. А., Корнелюк А. И. Мониторинг конформационного изменения окружения флуорофора $\operatorname{Trp} 144$ в С-модуле тирозил-тРНК синтетазы при тепловой денатурации // Доп. НАН України.-2004.—№ 1.—С. 156-161.

5. Kordysh M., Kornelyuk A. Conformational flexibility of cytokine-like C-module of tyrosyl-tRNA synthetase monitored by Trp144 intrinsic fluorescence // J. Fluoresc.-2006.-16.-P.705-711.

6. Кордиш М. О., Корнелюк О. І. Вивчення взаємодії С-модуля тирозил-тРНК

синтетази 3 тРНК методами флуоресцентної спектроскопії // Біополімери і клітина.-2006.-19, № 5.-С. 436- 439.

7. Simos G., Segref A., Fasiolo F., Hellmuth H., Shevchenko A., Mann M., Hurt E. C. The yeast protein Arc1p binds to tRNA and functions as a cofactor for the methionyl- and glutamyl-tRNA synthetase // The EMBO J.-1996.-15.-P. 5537-5548.

8. Kushiro T., Schimmel T. Trbp111 selectively binds a noncovalently assembled tRNA-like structure // Proc. Nat. Acad. Sci. USA.-2002.-99.-P. 16631-16635.

9. Shalak V., Kaminska M., Mitnacht-Kraus R., Vandenabeele P., Clauss M., Mirande M. The EMAPII cytokine is released from the mammalian multisynthetase complex after cleavage of its p43/proEMAPII component // J. Biol. Chem.-2001.-276.-P. $23769-23776$.

10. Murzin A. OB (oligonucleotide/oligosaccharide binding)-fold: common structural and functional solution for non-homologous sequences // EMBO J.-1993.-12.-P. 861-867.

11. Livesey A. K., J. C. Analyzing the distribution of decay constants in pulse-fluorimetry using the maximum entropy method Brochon // Biophys. J.-1987.-52.-P. 693-706.

12. Lakowicz J. R. Principles of fluorescent spectroscopy.-New York: Plenum press, 1999. $698 \mathrm{p}$. 
13. Каниболоцкий Д. С., Одынец К. А., Скурский С. И., Корнелюк А. И. Изучение внутримолекулярной подвижности цитокин-подобного С-концевого модуля тирозил-тРНК синтетазы млекопитающих методом молекулярной динамики

// Фізика живого.-2003.-11, № 2.-С. 61-71.

14. Chen Y., Liu B., Yu H.-T., Barkley M. D. The peptide bond quenches indole fluorescence // Am. Chem. Soc.-1996.-118.-P. 9271-9278.

15. Chen Y., Barkley M. D. Toward understanding tryptophan fluorescence in proteins // Biochemistry.-1998.-37.-P.9976-9982.

16. McMahon L. P., Yu H.-T., Vela M. A., Morales G. A., Shui L., Fronczek F. R., McLaughlin M. L., Barkley M. D. Conformer interconversion in the excited state of constrained tryptophan derivatives // J. Phys. Chem.-1997.-101.-P.3269-3280.

17. Sillen A., Hennecke J., Roethlisberger D., Glockshuber R., Engelborghs Y. Fluorescence quenching in the DsbA protein from Escherichia coli: complete picture of the excited-state energy pathway and evidence for the reshuffling dynamics of the microstates of tryptophan // Proteins.-1999.-37.-P.252-263.

Надійшла до редакціі 30.08 .06 